\title{
Studies on Production of Single Cell Protein by Aspergillus niger in Solid State Fermentation of Rice Bran
}

\author{
Anupama $^{1}$ and Pogaku Ravindra ${ }^{2 *}$ \\ ${ }^{1}$ School of Biotechnology, Institute of Post Graduate Studies \& Research, Jawaharlal Nehru Technological \\ University, Mahaveer marg, Hyderabad $500028 .{ }^{2}$ Food Technology Division, College of Technology, Osmania \\ University, Hyderabad 500007.
}

\begin{abstract}
An attempt was made to apply the solid state fermentation (SSF) for the production of single cell protein (SCP) using oil free rice bran waste as substrate. A local isolate of Aspergillus niger, was used as protein source for the studies. Total proteins were extracted to estimate the mycelial biomass from the moldy bran. Carbonate-bicarbonate extraction buffer and a pH 10 was found to be most efficient among the buffers used for the extraction of the proteins from the organism. The effect of supplementation by various sources of nitrogen and mineral solution on the final biomass yield was compared. The influence of $C / N$ ratio on the protein yield was also studied. Sodium nitrate at $C / N$ ratio of 1.387 was found to be an effective nitrogen-supplementing source, as it gave the higher biomass yield.
\end{abstract}

Key words: Single cell protein, Solid State Fermentation, Aspergillus niger, Rice bran, C/N ratio

\section{INTRODUCTION}

Solid state fermentation (SSF) is growth of microorganisms on predominantly insoluble substrate where there is no free liquid. Generally, under combined conditions of low water activity and presence of intractable solid substrate, fungi show luxuriant growth. Mycelial tips of fungi have immense turgor pressure, which assist in their penetration of hard substrate. Hence, proper growth of fungi in SSF gives much higher concentration of the biomass and higher yield when compared to submerged fermentation.

The advantage in SSF process is the unique possibility of efficient utilization of waste as the substrate to produce commercially viable products.
The process does not need elaborate prearrangements for media preparation. The process of SSF initially concentrated on enzyme production. But presently, there is worldwide interest for single cell protein (SCP) production due to the dwindling conventional food resources (Pandey \& Soccol, 1998; Tengerdy, 1985; Rodriguez-Vazquez et al., 1992; Zadrazil \& Puniya, 1995; Nigam \& Singh, 1994).

\section{MATERIALS AND METHODS}

Microorganism: A bcal isolate of Aspergillus niger, from decaying wood in the soil, was used for the experimental studies. The culture was

\footnotetext{
* Author for correspondence
} 
maintained on PDA slants at $28 \pm 2^{\circ} \mathrm{C}$. The subculturing was done once in a fortnight.

Substrate preparation: Oil free rice bran waste was procured from a local rice mill. It was pretreated to remove lignin and to expose the inner cellulose fibers to cellulolytic attack by the organism. The pretreatment process was carried out by adding one liter of $1 \%$ sodium hydroxide to $100 \mathrm{~g}$ of rice bran waste and autoclaving at $121^{\circ} \mathrm{C}$ and at $15 \mathrm{psi}$ for $30 \mathrm{~min}$. The pretreated rice bran was allowed to cool and subsequently filtered and washed to neutral $\mathrm{pH}$. Then it was then dried at $60^{\circ} \mathrm{C}$ in an oven for $12 \mathrm{~h}$. The dried bran was milled and sieved to obtain 50-mesh size and kept ready for SSF process.

Inoculum: Spores were harvested from a week old A. niger in five $\mathrm{ml}$ of sterile distilled water. Two $\mathrm{ml}$ of spore suspension was added to the pretreated rice bran based medium.

Fermentation medium and analytical me thods: Standardization of protein extraction buffer: Different buffers namely; citrate $(\mathrm{pH}$ 5.0), phosphate $(\mathrm{pH} 7.0)$ and carbonate-bicarbonate $(\mathrm{pH}$ 10.0) were used for the extraction of total proteins from $A$. niger. The organism was cultured by submerged fermentation in Modified Czapeck Dox Medium (MCD medium) in order to obtain the mycelium. The medium contained the following ingredients $(\mathrm{g} / 100 \mathrm{ml}): \mathrm{K}_{2} \mathrm{HPO}_{4}, 0.12 ; \mathrm{MgSO}_{4}$, $0.06 ; \mathrm{FeSO}_{4}, 0.05 ; \mathrm{KCl}, 0.02 ; \mathrm{NaNO}_{3}, 0.3$ and sucrose, 3.0. Four sets of $100 \mathrm{ml}$ each of MCD media was inoculated by $A$. niger. These were kept on a shaker at $120-150 \mathrm{rpm}$ and $28 \pm 2^{\circ} \mathrm{C}$ for eight days before harvesting.

The fungal mycelia were harvested by centrifugation at $2500 \mathrm{rpm}$. It was then homogenized at $6000 \mathrm{rpm}$ using citrate buffer and centrifuged subsequently at $6000 \mathrm{rpm}$ for $45 \mathrm{~min}$. The temperature during the course of extraction was maintained at $4 \mathrm{C}$. The supernatant obtained was used for estimating protein content. Same procedure was adopted for carbonate-bicarbonate buffer and also for phosphate buffer.

Sodium hydroxide solution was also used for extraction of proteins in addition to the buffers.

$0.1 \mathrm{~N}$ sodium hydroxide was added to the weighed mycelial mass followed by boiling at $80^{\circ} \mathrm{C}$ for 5 min and then was centrifuged at $6000 \mathrm{rpm}$ and $4^{\circ} \mathrm{C}$ to obtain the supernatant.
Growth of Aspergillus niger by solid state fermentation:

The mineral solution and different nitrogen sources were added in various combinations to 500 $\mathrm{ml}$ Erlenmeyer's flasks containing $10 \mathrm{~g}$ of pretreated rice bran (Table 1). Mineral solution was prepared by mixing $\mathrm{ZnSO}_{4} .7 \mathrm{H}_{2} \mathrm{O}, 0.008 \mathrm{~g}$; $\mathrm{FeSO}_{4} .7 \mathrm{H}_{2} \mathrm{O}, 0.008 \mathrm{~g}$ and $\mathrm{CuSO}_{4} \cdot 7 \mathrm{H}_{2} \mathrm{O}, 0.008 \mathrm{~g}$ in $100 \mathrm{ml}$ of $0.2 \mathrm{~N} \mathrm{HCl}$. The nitrogen stock solutions were prepared by adding $0.05 \mathrm{~g}$ of the compound i.e., sodium nitrate, ammonium nitrate and ammonium sulphate and $10 \mathrm{ml}$ of distilled water respectively. The flasks were made in triplicates and autoclaved at $121^{\circ} \mathrm{C}$ at $15 \mathrm{psi}$ for 20 min. These were inoculated with $2 \mathrm{ml}$ of spore suspension of A. niger. The contents of the flask were tapped gently to mix the spore suspension in the fermentation medium. All these flasks were incubated at $28 \pm 2^{\circ} \mathrm{C}$ for eight days.

The contents of each flask were harvested, weighed separately and homogenized in a homogeniser. Carbonate-bicarbonate buffer was used during the homogenization. The homogenized contents of sample from each flask were centrifuged at $6000 \mathrm{rpm}$ for $45 \mathrm{~min}$. The supernatant volume was measured and used for further analysis.

For estimation of total sugars, one $g$ of the substrate was suspended in $60 \mathrm{ml}$ of distilled water. This was kept at an ambient temperature for $12 \mathrm{~h}$ for the extraction of sugars as soaking makes the bran softer. The filtrate was then analyzed for sugars (Moniruzzaman, 1996) by using anthrone reagent (Ashwell, 1957). The biomass was expressed in terms of total protein content. Protein estimation was done by Folin method of Lowry et al. (1951).

\section{RESULTS AND DISCUSSIONS}

Rice bran is one of the most abundant and locally available agricultural wastes. Rice bran showed higher carbon content after pretreatment with alkali (carbon content $=3.458 \mathrm{mg} / \mathrm{g}$ of rice bran).

Among the extraction buffers used carbonatebicarbonate buffer at $\mathrm{pH} 10$ was found to be most efficient in extracting out total proteins of A. niger. The protein yield with various buffers was as follows (mg/g of sample): citrate buffer, 3.403; phosphate buffer, 6.351; carbonate-bicarbonate, 
6.884 and sodium hydroxide $(0.1 \mathrm{~N}), 3.154$. The biomass in terms of the final protein content of the moldy bran harvested on the eighth day is shown in the Table 2 and Fig.1.

Rice bran when supplemented with mineral solution and nitrogen sources individually or together improved the biomass yield (expressed in terms of total protein yield). Among all these combinations, the supplementation of rice bran with sodium nitrate gave the highest protein yield. Supplementation of rice bran with mineral solution individually also improved the biomass yield. But the biomass yield was not as high as that with the sodium nitrate supplementation. Individual nitrogen sources in combination with mineral solution supported the biomass yield to a lesser extent as compared to sodium nitrate or mineral solution (Table 2).

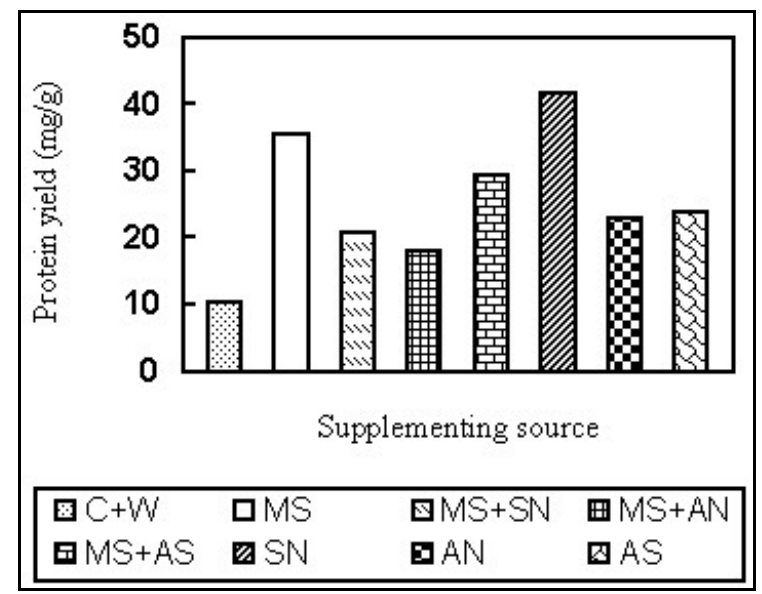

Figure 1 - Effect of supplementation on the final protein yield

Where, $C+W$ (Control + Water), MS (Mineral solution), $M S+S N$ (Mineral solution + Sodium nitrate), $M S+A N$ (Mineral solution + Ammonium nitrate), $M S+A S$ (Mineral solution + Ammonium sulfate), SN (Sodium nitrate), AN (Ammonium nitrate) and AS (Ammonium sulfate) are different media compositions provided for the cultivation of the biomass

The relation between $\mathrm{C} / \mathrm{N}$ ratio and final biomass yield (in terms of protein yield) is given in Table 2. The change in $\mathrm{C} / \mathrm{N}$ ratio was observed due to supplementation. The $\mathrm{C} / \mathrm{N}$ for pretreated rice bran was 1.729. The highest biomass yield was obtained when the $\mathrm{C} / \mathrm{N}$ was 1.387 . The high biomass yield was also observed for $\mathrm{C} / \mathrm{N} 1.729$ when mineral solution supplemented the medium.
But the results in Table 3 indicated that $\mathrm{C} / \mathrm{N}$ ratio was not the only factor controlling the final biomass yield. This was because when same $\mathrm{C} / \mathrm{N}$ ratios were maintained by various sources the protein yield was not similar. Even under the conditions of same $\mathrm{C} / \mathrm{N}$, sodium nitrate still favours the organism to grow better giving a higher biomass yield when compared to other nitrogen sources.

From the above observations it is clear that the availability of the nitrogen is the major controlling factor in the final biomass yield. Supplementation with mineral solution individually, gives higher yield because it provides continuous acidic medium to support the growth. As the organism grows in this condition it produces more of cellulases. These enzymes make available more of glucose monomers from the rice bran in the medium as well as help in the release of nitrogen for the growth.

The biomass yield was the highest when sodium nitrate supplements the medium alone. But when it was used along with the mineral solution its free availability for the growth seems to be hindered. Therefore, the protein yield, which was around $41.68 \mathrm{mg} / \mathrm{g}$ of rice bran, drops to almost half to $22.88 \mathrm{mg} / \mathrm{g}$ of rice bran. The contributing factor for the drastic reduction in the biomass yield could be traced to the reactivity of sodium ion. Sodium is placed higher than all the metals in mineral solution viz., zinc, ferrous, cuprous and hydrogen ions in the activity series of metals. Hence, it displaces all these metals from their salts. The nitrate ion released from sodium nitrate in the medium (due to the above principle of displacement) reacted with the free cations of the mineral solution and formed nitrates. As a result, free nitrogen and also mineral solution controlling the $\mathrm{pH}$ was not available as before to support the growth of $A$. niger.

Ammonium nitrate or ammonium sulphate when supplemented the medium along with mineral solution gave higher protein yield when compared to medium supplemented by sodium nitrate along with mineral solution. This was because the activity of mineral solution was not hindered, as ammonium ion formed was weak and hence unable to replace the metal ions in mineral solution. So the mineral solution controlled the $\mathrm{pH}$ and helped in the release of glucose as explained above and ammonium ion supplemented the nitrogen simultaneously. 
Table 1 - Composition of the fermentation media used

\begin{tabular}{|c|c|c|c|}
\hline Flask number & Pretreated rice bran $(\mathrm{g})$ & Mineral solution & $\begin{array}{c}\text { Nitrogen source } \\
\text { (from the stock solution) }\end{array}$ \\
\hline Control & 10 & Not added & Not added \\
\hline Control with water & 10 & Not added & Not added \\
\hline Sample 1 & 10 & $6 \mathrm{ml}$ & Not added \\
\hline Sample 2 & 10 & $5 \mathrm{ml}$ & $1 \mathrm{ml} \mathrm{NaNO}_{3}$ \\
\hline Sample 3 & 10 & $5 \mathrm{ml}$ & $1 \mathrm{ml} \mathrm{NH}_{4} \mathrm{NO}_{3}$ \\
\hline Sample 4 & 10 & $5 \mathrm{ml}$ & $1 \mathrm{ml}\left(\mathrm{NH}_{4}\right)_{2} \mathrm{SO}_{4}$ \\
\hline Sample 5 & 10 & Not added & $6 \mathrm{ml} \mathrm{NaNO} 3$ \\
\hline Sample 6 & 10 & Not added & $6 \mathrm{ml} \mathrm{NH} \mathrm{NO}_{3}$ \\
\hline Sample 7 & 10 & Not added & $6 \mathrm{ml}\left(\mathrm{NH}_{4}\right)_{2} \mathrm{SO}_{4}$ \\
\hline
\end{tabular}

Table 2 - Final protein yield in various media combinations

\begin{tabular}{lccc}
\hline Contents of the flask & $\begin{array}{c}\text { Protein yield } \\
(\mathrm{mg} / \mathrm{g} \text { of moldy rice bran) }\end{array}$ & $\begin{array}{c}\text { Net protein yield } \\
(\mathrm{mg} / \mathrm{g} \text { of rice bran })\end{array}$ & C/N ratio \\
\hline Control & 2.00 & 0 & 1.729 \\
Control with water & 12.48 & 10.48 & 1.729 \\
$\mathrm{PRB}^{*}+\mathrm{MS}^{* *}$ & 37.44 & 35.44 & 1.729 \\
$\mathrm{PRB}+\mathrm{MS}+\mathrm{NaNO}_{3}$ & 22.88 & 20.88 & 1.66 \\
$\mathrm{PRB}+\mathrm{MS}+\mathrm{NH}_{4} \mathrm{NO}_{3}$ & 20.08 & 18.08 & 1.589 \\
$\mathrm{PRB}+\mathrm{MS}+\left(\mathrm{NH}_{4}\right)_{2} \mathrm{SO}_{4}$ & 31.20 & 29.20 & 1.639 \\
$\mathrm{PRB}+\mathrm{NaNO}$ & 43.68 & 41.68 & 1.387 \\
$\mathrm{PRB}+\mathrm{NH}_{4} \mathrm{NO}_{3}$ & 24.96 & 22.96 & 1.134 \\
$\mathrm{PRB}+\left(\mathrm{NH}_{4}\right)_{2} \mathrm{SO}_{4}$ & 26.00 & 24.00 & 1.300 \\
\hline
\end{tabular}

"Pretreated rice bran " Mineral Solution

Table 3 - Final protein yield at same $\mathrm{C} / \mathrm{N}$ ratio but differ nitrogen source

\begin{tabular}{lcc}
\hline Contents of the flask & Net protein yield $(\mathrm{mg} / \mathrm{g}$ of rice bran) & C/N ratio \\
\hline Control (PRB+water) & 0 & 1.729 \\
PRB ${ }^{*}+\mathrm{MS}^{* *}$ & 34.2 & 1.729 \\
$\mathrm{PRB}+\mathrm{MS}+\mathrm{NaNO}_{3}$ & 22.4 & 1.387 \\
$\mathrm{PRB}+\mathrm{MS}+\mathrm{NH}_{4} \mathrm{NO}_{3}$ & 20.93 & 1.387 \\
$\mathrm{PRB}+\mathrm{MS}+\left(\mathrm{NH}_{4}\right)_{2} \mathrm{SO}_{4}$ & 30.03 & 1.387 \\
$\mathrm{PRB}+\mathrm{NaNO}_{3}$ & 40.91 & 1.387 \\
$\mathrm{PRB}+\mathrm{NH}_{4} \mathrm{NO}_{3}$ & 22.09 & 1.387 \\
$\mathrm{PRB}+\left(\mathrm{NH}_{4}\right)_{2} \mathrm{SO}_{4}$ & 24.10 & 1.387 \\
\hline
\end{tabular}

\footnotetext{
Pretreated rice bran "Mineral Solution
} 
List of revisions/modifications made in the manuscript as suggested by the reviewer:

\begin{tabular}{|c|c|c|}
\hline Query & Title, Paragraph, Line etc. & Response \\
\hline $\begin{array}{l}\text { Anupama - Is the name } \\
\text { complete }\end{array}$ & Title-Author names & Yes \\
\hline What size? How? & $\begin{array}{l}\text { Heading: Materials and Methods } \\
\text { Subheading: Substrate preparation } \\
\text { Penultimate line }\end{array}$ & $\begin{array}{l}\text { The dried bran was milled and } \\
\text { sieved to obtain } 50 \text { mesh size. } \\
\text { (Change incorporated in the text) }\end{array}$ \\
\hline For what? & $\begin{array}{l}\text { Heading: Materials and Methods } \\
\text { Subheading: Fermentation medium \& } \\
\text { analytical methods } \\
2^{\text {nd }} \text { paragraph, } 10^{\text {th }} \text { line }\end{array}$ & $\begin{array}{l}\text { The necessary corrections were } \\
\text { incorporated in the text. }\end{array}$ \\
\hline $\begin{array}{l}\text { Conditions of } \\
\text { centrifugations? }\end{array}$ & $\begin{array}{l}\text { Heading: Materials and Methods } \\
\text { Subheading: Fermentation medium \& } \\
\text { analytical methods } \\
\text { 3rd paragraph, } 7^{\text {th }} \text { line }\end{array}$ & $\begin{array}{l}\text {----for } 5 \mathrm{~min} \text { and then was } \\
\text { centrifuged at } 6000 \mathrm{rpm} \& 4^{\circ} \mathrm{C} \text { to } \\
\text { obtain the supernatant------ } \\
\text { Incorporated in the text }\end{array}$ \\
\hline Why? & $\begin{array}{l}\text { Heading: Materials and Methods } \\
\text { Subheading: Growth of Aspergillus } \\
\text { niger by solid state fermentation } \\
\text { Penultimate paragraph, } 4^{\text {th }} \text { line }\end{array}$ & $\begin{array}{l}\text { This was kept at an ambient } \\
\text { temperature for } 12 \mathrm{~h} \text { for the } \\
\text { extraction of sugars as soaking } \\
\text { makes the bran softer. }\end{array}$ \\
\hline Tables $1,2,3 \& 5$ & General comments & $\begin{array}{l}\text { Deleted as per the instructions and } \\
\text { the summarized matter incorporated } \\
\text { in the text at appropriate places. }\end{array}$ \\
\hline $\begin{array}{l}\text { Was the strain of } A . \text { niger } \\
\text { isolated by the authors or } \\
\text { obtained from some source? }\end{array}$ & General comments & $\begin{array}{l}\text { The strain was isolated locally from } \\
\text { the decayed wood lying in the soil. } \\
\text { Mentioned in 'Materials and } \\
\text { Methods' ---'Micro-organism' } \\
\text { section. }\end{array}$ \\
\hline $\begin{array}{l}\text { Is there any accession } \\
\text { number for it? }\end{array}$ & General comments & $\begin{array}{l}\text { No (Not available with us as the } \\
\text { organism being locally isolated) }\end{array}$ \\
\hline $\begin{array}{l}\text { Changes in the Title of } \\
\text { paper }\end{array}$ & Title & $\begin{array}{l}\text { p-changed to 'upper case' } \\
\text { from-replaced by 'by' } \\
\text { by-replaced by 'in' }\end{array}$ \\
\hline $\begin{array}{l}\text { Addresses of Institutions } \\
\text { not as per the journal } \\
\text { guidelines }\end{array}$ & Addresses of the authors & $\begin{array}{l}\text { Changed as per directions and } \\
\text { author guidelines }\end{array}$ \\
\hline $\begin{array}{l}\text { Email address of the } \\
\text { corresponding author }\end{array}$ & Addresses of the authors & $\begin{array}{l}\text { Deleted form the author address title } \\
\text { and incorporated as 'footnote' on the } \\
\text { same page }\end{array}$ \\
\hline $\begin{array}{l}\text { Submerged fermentation---- } \\
\text {-------alternative } \\
\text { techniques. }\end{array}$ & Abstract, $1^{\text {st }}$ paragraph, $1^{\text {st }}$ line & Deleted as required \\
\hline Is & Abstract, $1^{\text {st }}$ paragraph, $4^{\text {th }}$ line & Replaced with 'was' \\
\hline Technique & Abstract, $1^{\text {st }}$ paragraph, $4^{\text {th }}$ line & $\begin{array}{l}\text { Replaced with 'solid state } \\
\text { fermentation' }\end{array}$ \\
\hline Single Cell Protein & Abstract, $1^{\text {st }}$ paragraph, $4^{\text {th }}$ line & 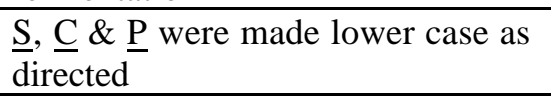 \\
\hline Aspergillus niger & Abstract, $1^{\text {st }}$ paragraph, $5^{\text {th }}$ line & Made 'not italic' \\
\hline $\begin{array}{l}\text { which grows well on } \\
\text { lignocellulosic wastes }\end{array}$ & Abstract, $1^{\text {st }}$ paragraph, $5^{\text {th }}-6^{\text {th }}$ line & Deleted as suggested \\
\hline The effect---- & Abstract, $2^{\text {nd }}$ paragraph, $1^{\text {st }}$ line & $\begin{array}{l}\text { Shifted and made continuous with } \\
\text { the } 1^{\text {st }} \text { paragraph as directed }\end{array}$ \\
\hline Italicized 'Keywords--' & Keywords & Made 'normal \& not italic' \\
\hline
\end{tabular}


List of revisions/modifications (cont.).

\begin{tabular}{|c|c|c|}
\hline $\begin{array}{l}\text { Numbering in front of all } \\
\text { the heading viz., } \\
\text { Introduction, Materials and } \\
\text { Methods etc., etc. }\end{array}$ & All the Headings and subheadings & $\begin{array}{l}\text { Removed the numbers as well as the } \\
\text { tab space as directed. Also the } \\
\text { paragraphs started with a 'tab space' } \\
\text { as directed in the manuscript. }\end{array}$ \\
\hline Solid S State Fermentation & $\begin{array}{l}\text { Heading: Introduction } \\
1^{\text {st }} \text { paragraph, } 1^{\text {st }} \text { line }\end{array}$ & $\underline{\mathrm{S}} \& \underline{\mathrm{F}}$ made 'lower case' as directed \\
\hline $\begin{array}{l}\text { Hence, proper------to } \\
\text { submerged fermentation }\end{array}$ & $\begin{array}{l}\text { Heading: Introduction } \\
1^{\text {st }} \text { paragraph, last line }\end{array}$ & Full stop incorporated \\
\hline The advantage----- & $\begin{array}{l}\text { Heading: Introduction } \\
2^{\text {nd }} \text { paragraph, } 1^{\text {st }} \text { line }\end{array}$ & $\begin{array}{l}\text { Tab space at the start of new } \\
\text { paragraph. }\end{array}$ \\
\hline Single $\underline{\text { Cell }}$ Protein & $\begin{array}{l}\text { Heading: Introduction } \\
2^{\text {nd }} \text { paragraph, } 9^{\text {th }} \text { line }\end{array}$ & $\underline{\mathrm{S}}, \underline{\mathrm{C}} \& \underline{\mathrm{P}}$ made lower case as \\
\hline Page numbers & All pages & Deleted as instructed \\
\hline $\begin{array}{l}\text { Spacing between the text } \\
\text { columns and other text } \\
\text { margins, spacing etc. }\end{array}$ & All pages & $\begin{array}{l}\text { Made as per the journal guidelines } \\
\text { and instructions in the original } \\
\text { (revised) manuscript. }\end{array}$ \\
\hline Selected organism & $\begin{array}{l}\text { Heading: Materials and Methods } \\
\text { Subheading: Selected organism }\end{array}$ & $\begin{array}{l}\text { Changed to 'micro-organism:' as } \\
\text { directed }\end{array}$ \\
\hline A local isolate----- & $\begin{array}{l}\text { Heading: Materials and Methods } \\
\text { Subheading: Selected organism }\end{array}$ & Shifted as directed in the text \\
\hline Cultures were & $\begin{array}{l}\text { Heading: Materials and Methods } \\
\text { Subheading: Selected organism } \\
3^{\text {rd }} \text { line }\end{array}$ & Changed to 'culture was' \\
\hline The cultures----sporulation' & $\begin{array}{l}\text { Heading: Materials and Methods } \\
\text { Subheading: Selected organism } \\
\text { Last line }\end{array}$ & Deleted as directed \\
\hline Substrate preparation & $\begin{array}{l}\text { Heading: Materials and Methods } \\
\text { Subheading: Substrate preparation }\end{array}$ & Changed to 'Substrate preparation:' \\
\hline Oil free---- & $\begin{array}{l}\text { Heading: Materials and Methods } \\
\text { Subheading: Substrate preparation }\end{array}$ & Shifted as directed \\
\hline 12hours & $\begin{array}{l}\text { Heading: Materials and Methods } \\
\text { Subheading: Substrate preparation } \\
12^{\text {th }} \text { line }\end{array}$ & Changed to ' $12 \mathrm{~h}$ ' as required \\
\hline Inoculum & $\begin{array}{l}\text { Heading: Materials and Methods } \\
\text { Subheading: Inoculum }\end{array}$ & Changed to 'Inoculum:" \\
\hline A week old----- & $\begin{array}{l}\text { Heading: Materials and Methods } \\
\text { Subheading: Inoculum } \\
\text { Start of the paragraph }\end{array}$ & $\begin{array}{l}\text { Changed to 'Spores were harvested } \\
\text { from a week old } A \text {. niger in five ml } \\
\text { of distilled water. Two ml of spore } \\
\text { suspension was added--------.' As } \\
\text { directed in the original text. The } \\
\text { starting sentence was also shifted as } \\
\text { required }\end{array}$ \\
\hline $\begin{array}{l}\text { Standardization of protein } \\
\text { extraction buffer: }\end{array}$ & $\begin{array}{l}\text { Heading: Materials and Methods } \\
\text { Subheading: Fermentation medium } \\
\text { and analytical methods } \\
\text { Sub subheading: Standardization of } \\
\text { protein extraction buffer: }\end{array}$ & $\begin{array}{l}\text { The sub subheading was made italic } \\
\text { as required. } 1^{\text {st }} \text { sentence of the } \\
\text { paragraph shifted as required }\end{array}$ \\
\hline
\end{tabular}


List of revisions/modifications (cont.).

\begin{tabular}{|c|c|c|}
\hline Aspergillus niger & Throughout the manuscript & $\begin{array}{l}\text { Changed to } A \text {. niger at all places as } \\
\text { directed }\end{array}$ \\
\hline For this purpose & $\begin{array}{l}\text { Heading: Materials and Methods } \\
\text { Subheading: Fermentation medium } \\
\text { and analytical methods } \\
\text { Sub subheading: Standardization of } \\
\text { protein extraction buffer: } \\
1^{\text {st }} \text { paragraph, } 3^{\text {rd }} \text { line }\end{array}$ & Deleted as required \\
\hline 4 sets & $\begin{array}{l}\text { Heading: Materials and Methods } \\
\text { Subheading: Fermentation medium } \\
\text { and analytical methods } \\
\text { Sub subheading: Standardization of } \\
\text { protein extraction buffer: } \\
1^{\text {st }} \text { paragraph, } 7^{\text {th }} \text { line }\end{array}$ & Changed to 'Four' \\
\hline From 7day old PDA slants & $\begin{array}{l}\text { Heading: Materials and Methods } \\
\text { Subheading: Fermentation medium } \\
\text { and analytical methods } \\
\text { Sub subheading: Standardization of } \\
\text { protein extraction buffer: } \\
1^{\text {st }} \text { paragraph, } 9^{\text {th }} \text { line }\end{array}$ & Deleted as directed \\
\hline $\begin{array}{l}\text { The fungus was obtained---- } \\
\text {-growth and was }\end{array}$ & $\begin{array}{l}\text { Heading: Materials and Methods } \\
\text { Subheading: Fermentation medium } \\
\text { and analytical methods } \\
\text { Sub subheading: Standardization of } \\
\text { protein extraction buffer: } \\
\text { 2nd paragraph, } 1^{\text {st }} \text { line }\end{array}$ & $\begin{array}{l}\text { Modified to 'The fungal mycelia } \\
\text { were harvested----- }\end{array}$ \\
\hline $2500 \mathrm{rpm}$ & $\begin{array}{l}\text { Heading: Materials and Methods } \\
\text { Subheading: Fermentation medium } \\
\text { and analytical methods } \\
\text { Sub subheading: Standardization of } \\
\text { protein extraction buffer: } \\
\text { 2nd paragraph, } 4^{\text {th }} \text { line }\end{array}$ & Changed to '2500 rpm' \\
\hline The pellet was weighed & $\begin{array}{l}\text { Heading: Materials and Methods } \\
\text { Subheading: Fermentation medium } \\
\text { and analytical methods } \\
\text { Sub subheading: Standardization of } \\
\text { protein extraction buffer: } \\
\text { 2nd paragraph, } 4^{\text {th }} \text { line }\end{array}$ & Deleted as needed \\
\hline $\begin{array}{l}\text { The homogenized sample } \\
\text { was }\end{array}$ & $\begin{array}{l}\text { Heading: Materials and Methods } \\
\text { Subheading: Fermentation medium } \\
\text { and analytical methods } \\
\text { Sub subheading: Standardization of } \\
\text { protein extraction buffer: } \\
2^{\text {nd }} \text { paragraph, } 6^{\text {th }} \text { line }\end{array}$ & Replaced with 'and' \\
\hline
\end{tabular}


List of revisions/modifications (cont.).

\begin{tabular}{|c|c|c|}
\hline $\begin{array}{l}\text { As this solution --------- } \\
\text { conventionally }\end{array}$ & $\begin{array}{l}\text { Heading: Materials and Methods } \\
\text { Subheading: Fermentation medium } \\
\text { and analytical methods } \\
\text { Sub subheading: Standardization of } \\
\text { protein extraction buffer: } \\
\text { 3rd paragraph, } 3^{\text {rd }} \text { line }\end{array}$ & Deleted as required \\
\hline $5 \mathrm{~min}$ & $\begin{array}{l}\text { Heading: Materials and Methods } \\
\text { Subheading: Fermentation medium } \\
\text { and analytical methods } \\
\text { Sub subheading: Standardization of } \\
\text { protein extraction buffer: } \\
\text { 3rd paragraph, } 7^{\text {th }} \text { line }\end{array}$ & Changed to '5 min' \\
\hline The carbon----rice bran. & $\begin{array}{l}\text { Heading: Materials and Methods } \\
\text { Subheading: Fermentation medium } \\
\text { and analytical methods } \\
\text { Sub subheading: Growth of } \\
\text { Aspergillus niger by solid state } \\
\text { fermentation } \\
\text { 2nd paragraph, } 1^{\text {st }} \text { line }\end{array}$ & Deleted as required \\
\hline Tables $4,6 \& 7$ & Tables & $\begin{array}{l}\text { Changed as per the journal } \\
\text { guidelines i.e., The lines deleted as } \\
\text { instructed, Upper case letters made } \\
\text { to lower case in the Table title row, } \\
\text { Table was adjusted as per single } \\
\text { spacing and serial numbers were } \\
\text { deleted as directed. }\end{array}$ \\
\hline To remove the debris & $\begin{array}{l}\text { Heading: Materials and Methods } \\
\text { Subheading: Fermentation medium } \\
\text { and analytical methods } \\
\text { Sub subheading: Growth of } \\
\text { Aspergillus niger by solid state } \\
\text { fermentation } \\
3^{\text {rd }} \text { paragraph, } 7^{\text {th }} \text { line }\end{array}$ & Deleted as required \\
\hline $1 \mathrm{gm}$ & $\begin{array}{l}\text { Heading: Materials and Methods } \\
\text { Subheading: Fermentation medium } \\
\text { and analytical methods } \\
\text { Sub subheading: Growth of } \\
\text { Aspergillus niger by solid state } \\
\text { fermentation } \\
4^{\text {th }} \text { paragraph, } 1^{\text {st }} \text { line }\end{array}$ & Changed to 'one g' \\
\hline $\mathrm{mg} / \mathrm{gm}$ in Fig. 1 & $\begin{array}{l}\text { Heading: Results and discussions } \\
\text { Y-axis }\end{array}$ & Changed to 'mg/g' \\
\hline $\begin{array}{l}\text { It is used as sole carbon } \\
\text { source in SSF studies }\end{array}$ & $\begin{array}{l}\text { Heading: Results and discussions } \\
1^{\text {st }} \text { paragraph, } 2^{\text {nd }} \text { line }\end{array}$ & Deleted as required \\
\hline Has contained & $\begin{array}{l}\text { Heading: Results and discussions } \\
1^{\text {st }} \text { paragraph, } 4^{\text {th }} \text { line }\end{array}$ & Replaced with 'showed' \\
\hline $\begin{array}{l}\text { Rice bran is-------- } \\
\text { provided to the medium. }\end{array}$ & $\begin{array}{l}\text { Heading: Results and discussions } \\
4^{\text {th }} \text { paragraph, } 1^{\text {st }} \text { line }\end{array}$ & Deleted as directed \\
\hline Nitrogen source & $\begin{array}{l}\text { Heading: Results and discussions } \\
5^{\text {th }} \text { paragraph, } 2^{\text {nd }} \text { line }\end{array}$ & Deleted as directed \\
\hline
\end{tabular}


List of revisions/modifications (cont.).

\begin{tabular}{|c|c|c|}
\hline , & $\begin{array}{l}\text { Heading: Results and discussions } \\
5^{\text {th }} \text { paragraph, } 5^{\text {th }} \text { line }\end{array}$ & Deleted as directed \\
\hline Is & $\begin{array}{l}\text { Heading: Results and discussions } \\
\text { All the paragraphs } \\
\text { Heading: Conclusions } \\
\text { All the paragraphs }\end{array}$ & $\begin{array}{l}\text { Changed to 'was' where directed and } \\
\text { needed. }\end{array}$ \\
\hline Indicates & $\begin{array}{l}\text { Heading: Results and discussions } \\
8^{\text {th }} \text { paragraph, } 1^{\text {st }} \text { line }\end{array}$ & Changed to 'indicated' \\
\hline $\begin{array}{l}\text { However, the type of } \\
\text { nitrogen source used-------- } \\
\text { yield. The substrate, rice } \\
\text { bran------ }\end{array}$ & $\begin{array}{l}\text { Heading: Conclusions } \\
1^{\text {st }} \text { paragraph }\end{array}$ & $\begin{array}{l}\text { Changed to 'However rice bran } \\
\text { when supplemented ------' }\end{array}$ \\
\hline $\begin{array}{l}\text { Rice Bran, is one of the } \\
\text { most-----------near } \\
\text { future. }\end{array}$ & $\begin{array}{l}\text { Heading: Conclusions } \\
\text { Last paragraph }\end{array}$ & Deleted as directed \\
\hline References & Heading: References & $\begin{array}{l}\text { Changed as per the journal } \\
\text { guidelines and as per the instructions } \\
\text { in the text }\end{array}$ \\
\hline
\end{tabular}

\section{CONCLUSIONS}

A higher yield of SCP production from A. niger was possible by SSF of rice bran. Though, utilization of SSF for SCP production is emerging field, encouraging results are obtained and some success is achieved in improving the overall protein yield by supplementation of rice bran based SSF medium. The $\mathrm{C} / \mathrm{N}$ ratio was not very effective in controlling biomass yield but the supplementation of rice bran with various nitrogen sources or mineral solution separately or in combination improved the A. niger growth. The biomass yield was best with rice bran based medium with sodium nitrate as the nitrogen source for single cell protein production.

\section{ACKNOWLEDGEMENT}

Ms. Anupama acknowledges UGC-CSIR, New Delhi for the award of UGC-NET Fellowship.

\section{RESUMO}

Uma tentativa foi feita para aplicar fermentação no estado sólido (SSF) para a produção de "single cell protein"(SCP utilizando o resíduo livre de óleo farelo de arroz, como substrato. Uma cepa de
Aspergillus niger isolada do local foi usada como fonte de proteína para os estudos. As proteínas totais foram extraídas para estimar a biomassa micelial do farelo fermentado. A condição mais eficiente encontrada para extração das proteínas do microrganismo foi feita com tampão Carbonatobicarbonato $\mathrm{pH} 10$. Comparou-se o efeito da suplementação do substrato com várias fontes de nitrogênio e de solução no rendimento final da biomassa. Também estudou-se a influência da relação de $\mathrm{C} / \mathrm{N}$ no rendimento da proteína. A suplementação mais eficaz encontrada foi com nitrato de sódio com uma relação $\mathrm{C} / \mathrm{N}$ de 1,387 , resultando em maior rendimento de biomassa.

\section{REFERENCES}

Ashwell. G. (1957), Enzymology Vol.III, Academic Press, New York.

Lowry, O. H., Rosenbrough, N. J., Farr, A. I. and Randall, R. J. (1951), Protein measurement with the folin-phenol reagent. J. Biol. Chem., 193, 265-271.

Moniruzzaman, M. (1996), Effect of steam explosion on physiochemical properties and enzyme saccharification of rice straw. Appl. Biochem. Biotechnol., 59, 283-297.

Nigam, P. and Singh, D. (1994), Solid state (substrate) fermentation systems and their applications in biotechnology. J. Basic Microbiol., 34, 405-414. 
Pandey, A. and Soccol, C. R. (1998), Bioconversion of biomass: A case study of ligno-cellulosics Bioconversions in solid state fermentation. Brazilian Arch. Biol. Tech., 41 (4), 379-390.

Rodriguez-Vazquez, R., Villanuevaventure, G. and Riosleal, E. (1992), Sugar cane bagasse pith dry pretreatment for single cell protein production. Biores. Tech., 39, 17-22.

Tengerdy, R. P. (1985), Solid state fermentation. TIBTECH, 3, (4), 96-99.
Zadrazil, F. and Puniya, A. K. (1995), Studies on effect of particle size on solid state fermentation of sugar cane bagasse into animal feed using white rot fungi. Biores. Tech., 54, 85-87.

Received: January 05, 2000; Revised: April 05, 2000; Accepted: June 08, 2000. 